\title{
Pengaruh Kepemimpinan Dan Spiritualitas Di Tempat Kerja Terhadap Kinerja Pegawai Melalui Semangat Kerja Pada Pegawai Kantor Bupati Deli Serdang
}

\author{
Ayu Juliani Siregar \\ Universitas Muhammadiyah Sumatera Utara \\ Muis Fauzi Rambe \\ Universitas Muhammadiyah Sumatera Utara \\ Koresponden: muisfauzi@umsu.ac.id
}

\begin{abstract}
The purpose of this study was to examine and analyze the influence of leadership and spirituality in the workplace on employee performance through the morale of the Deliserdang regent's office employees directly or indirectly. The approach used in this study is a causal approach. The population in this study were all employees of the Deliserdang regent's office. The sample in this study using the slovin formula totaling 52 employees of the Deliserdang regent's office. Data collection techniques in this study used questionnaire methode. The data analysis technique in this study uses a quantitative approach using statistical analysis by using the Auter Model Analysis test, Inner Model Analysis, and Hypothesis Testing. Data processing in this study using the PLS (Partial Least Square) software program. The results of this study prove that leadership has a significant effect on performance directly, spirituality in the workplace has a significant effect on performance, direct morale has a significant effect on performance, direct leadership has a significant effect on morale, and spirituality in the workplace has a significant effect, on work morale indirectly work morale is able to mediate the influence of leadership onperformance, endirectly work morale is able to mediate the influence of spirituality in the workplace on the performance of the Deli Serdang regent's office employee.
\end{abstract}

Keywords Leadership, Workplace Spirituality, Work Spirit, Performance

\section{PENDAHULUAN}

Negara Indonesia adalah Negara Kesatuan yang berbentuk Republik, dimana dalam penyelenggaraan pemerintahan diberikan kesempatan dan keleluasan kepada daerah dalam menyelenggarakan Otonomi Daerah sebagai azas Desentralisasi. Sesuai dengan UU Nomor 32 Tahun 2004 sebagai pengganti UU Nomor 22 Tahun 1999 tentang Pemerintah Daerah, yang mana dalam UU tersebut dijelaskan bahwa Pemerintah daerah melalui azas desentralisasi, diberikan kewenangan untuk mengatur dan mengurus sendiri urusan pemerintahannya menurut kearifan lokal masing-masing daerah. Pemberian otonomi luas kepada daerah diarahkan untuk mempercepat terwujudnya kesejahteraan masyarakat melalui peningkatan pelayanan kepada masyarakat, pemberdayaan masyarakat, dan peran serta masyarakat. Disamping melalui otonomi luas, daerah diharapkan mampu meningkatkan daya saing dengan memperhatikan prinsip demokrasi, 
keadilan, pemerataan, keistimewaan dan kekhususan, serta potensi dan keanekaragaman daerah (Ernaldiwan, 2017)

Organisasi pemerintahan daerah merupakan lembaga yang menjalankan roda pemerintahan, dalam implementasi desentralisasi atau otonomi daerah, menuntut adanya faktor pendukung yang harus diperhatikan, salah satunya adalah manusia sebagai pelaku dan penggerak sistem pemerintahan sehingga berhasil atau tidaknya penyelenggaraan pemerintahan dan pembangunan daerah, sangat tergantung terhadap bagaimana mengelola atau mengatur sumber daya manusia yang terkait (aparatur daerah). Sesuai dengan UU nomor 5 tahun 2014 tentang Aparatur Sipil Negara, yang menjelaskan Aparatur Sipil Negara sebagai profesi bagi Pegawai Negeri Sipil dan pegawai pemerintah dengan perjanjian kerja yang berkerja pada instansi pemerintah, dan diangkat oleh pejabat pembina kepegawaian, serta diserahi tugas dalam suatu jabatan pemerintahan atau diserahi tugas negara lainnya dan digaji berdasarkan peraturan perundang-undangan. Namun sebagai bagian dari reformasi, dan dalam rangka pelaksanaan cita-cita bangsa dan mewujudkan tujuan negara, maka diperlukan manajemen Aparatur Sipil Negara dalam rangka menghasilkan Aparatur Sipil Negara yang profesional, memiliki nilai dasar, etika profesi, dan bersih dari praktik korupsi, kolusi, dan nepotisme (Ernaldiwan, 2017)

SDM aparatur adalah dimensi dan unik dibanding mengelola resources yang lain. Manusia memiliki sifat, karakter, motivasi dan emosi yang berbeda-beda sehingga membutuhkan penanganan/manage yang berbeda pula untuk setiap personalnya. Sumber daya manusia merupakan sumber daya terpenting pada setiap organisasi, dimana manusia sebagai penggerak dan pengelola sumber daya- sumber daya lainnya. Oleh karena itu, salah satu tanggung jawab organisasi adalah berusaha meningkatkan kinerja pegawainya dengan baik (Silpi et al., 2020). Kinerja atau performance merupakan kondisi yang harus diketahui dan diinformasikan kepada pihak-pihak tertentu untuk mengetahui tingkat pencapaian hasil suatu departemen yang dihubungkan dengan visi yang diemban suatu organisasi, serta mengetahui dampak positif dan negative suatu kebijakan operasional yang diambil. Kinerja dapat juga diartikan sebagai hasil kerja yang dicapai seseorang sesuai dengan ketentuan yang berlaku pada suatu kelompok (Yulianti, dkk, 2017).

Kinerja adalah penampilan yang melakukan, menggambarkan dan menghasilkan sesuatu hal, baik yang bersifat fisik dan non fisik yang sesuai dengan petunjuk, fungsi dan tugasnya yang didasari oleh pengetahuan, sikap dan keterampilan (Rahadi, 2014). Kepemimpinan merupakan faktor penting yang menentukan kinerja karyawan dan kemampuan organisasi beradaptasi dengan perubahan lingkungan. Kepemimpinan yang efektif harus memberikan pengarahan terhadap usaha-usaha semua pekerja dalam mencapai tujuan organisasi. Tanpa kepemimpinan, hubungan antara tujuan perseorangan dan tujuan organisasi mungkin menjadi tidak searah. Situasi ini akan menimbulkan keadaan dimana seorang karyawan dalam bekerja hanya untuk mencapai tujuan pribadinya, sementara itu keseluruhan organisasi menjadi tidak efisien dalam pencapaian tujuannya. Kepemimpinan merupakan suatu kemampuan yang melekat pada diri seorang yang memimpin yang tergantung dari macam-macam faktor baik faktor-faktor intern maupun faktor-faktor ekstern (Jufrizen, 2017).

Selain itu kepemimpinan merupakan salah satu faktor yang membentuk dan membantu orang lain untuk berkerja dan antusias mencapai tujuan yang direncanakan dalam kaitannya dengan keberhasilan organisasi mewujudkan tujuan sebagian besar ditentukan oleh kepemimpinan dan tingginya kinerja karyawan dalam melaksanakan tugas - tugasnya (Arianty, 2015). Melihat pentingnya kepemimpinan terhadap kinerja maka diperlukan pimpinan - pimpinan yang benar - benar dapat menjalankan fungsinya 
dengan tepat agar semua pihak yang ada didalam sebuah organisasi/perusahaan dapat menjalankan tugasnya dengan baik. Dalam kenyataannya para pemimpin dapat mempengaruhi moral dan kinerja, loyalitas kerja, keamanan, kualitas kehidupan kerja terutama tingkat kinerja suatu organisasi (Handoko, 2013).

Faktor lain yang berpengaruh terhadap kinerja adalah spiritualitas di tempat kerja. Spiritualitas di tempat kerja adalah pengakuan bahwa orang memiliki kehidupan jiwa yang memelihara dan terpelihara oleh sebuah pekerjaan, Hal ini bermakna dalam sebuah konsep keumuman orang. Artinya dalam organisasi dimana pegawai bekerja terdapat budaya spiritualitas yang memiliki nilai kepuasan batin yang tinggi. Dengan kata lain, spiritualitas di tempat kerja menciptakan pegawai yang memaknai pekerjaan lebih dari sekedar tempat mendapatkan penghasilan, akan tetapi lebih kepada sejauh mana pegawai tersebut dapat berkontribusi bagi organisasi sejalan dengan pemenuhan kebutuhan batinnya. Banyak orang di tempat kerja merasa butuh menemukan kembali apa yang mereka rawat dalam hidup ini dan mencoba menemukan pekerjaan yang disukainya (Robbins, 2012).

\section{LANDASAN TEORI Kinerja}

Kinerja merupakan suatu hasil kerja yang dihasilkan oleh seorang karyawan diartikan untuk mencapai tujuan yang diharapkan. Selain itu kinerja seorang karyawan merupakan hal yang bersifat individual, karena setiap karyawan mempunyai tingkat kemampuan yang berbeda - beda dalam mengerjakan tugasnya. Pihak manajemen dapat mengukur karyawan atas hasil kerjanya berdasarkan kinerja dari masing - masing karyawan. Kinerja dan bukan merupakan hasil yang dapat dilihat pada saat itu juga. Menurut (Mangkunegara, 2014) berpendapat bahwa kinerja karyawan adalah hasil kerja secara kualitas dan kuantitas yang dicapai oleh seseorang karyawan dalam melaksanakan tugasnya sesuai dengan tanggung jawab yang diberikan kepadanya.

Setiap manusia memiliki potensi untuk bertindak dalam berbagai bentuk aktivitas, kemampuan betindak tersebut diperoleh secara alamiah yang berasal dari sekitar kehidupan. Kinerja adalah suatu hasil yang dicapai oleh pekerja dalam pekerjaannya menurut kriteria tertentu yang berlaku untuk suatu pekerjaan. Indikator kinerja merupakan sesuatu yang akan dihitung dan diukur. Adapun indikator kinerja (Mangkunegara, 2014)menyatakan yaitu :

1. Kualitas kerja

Kualitas kerja adalah mutu yang harus dihasilkan dalam pekerjaan.

2. Kuantitas kerja

Kuantitas kerja adalah jumlah yang harus diselesaikan dan dicapai dalam pekerjaan.

3. Dapat tidaknya diandalkan

Dapat tidaknya diandalkan merupakan apakah seseorang karyawan dapat mengikuti

instruksi, memiliki inisiatif, hati-hati dan rajin dalam bekerja.

4. Sikap

Sikap yang dimiliki terhadap perusahaan, karyawan lain pekerjaan secara kerjasama.

Sedangkan menurut (Sutrisno, 2010)mengemukakan secara umum dapat dinyatakan bahwa terdapat 3 aspek indikator kinerja, yaitu sebagai berikut :

1. Kualitas

Kualitas yang dihasilkan, menerangkan tentang jumlah kesalahan, waktu dan ketepatan dalam melakukan tugas.

2. Kuantitas 
Kuantitas yang dihasilkan, berkenaan dengan berapa jumlah produk, serta masa kerja yang telah di jalani individu pegawai tersebut.

3. Waktu kerja

Waktu kerja menerangkan akan berapa jumlah absen, keterlambatan, serta masa kerja yang telah dijalani individu pegawa tersebut.

\section{Kepemimpinan}

Kepemimpinan adalah suatu perilaku dengan tujuan tertentu untuk mempengaruhi aktivitas para anggota kelompok untuk mencapai tujuan bersama yang dirancang untuk memberikan manfaat individu dan organisasi, sehingga dalam suatu organisasi kepemimpinan merupakan faktor yang sangat penting dalam menentukan pencapaian tujuan yang telah ditetapkan oleh organisasi. Menurut (Rivai, 2014) kepemimpinan pada dasarnya merupakan pola hubungan antara individu-individu yang menggunakan wewenang dan pengaruhnya terhadap kelompok orang agar bekerja bersama-sama untuk mencapai tujuan. Selanjutnya menurut (Sutrisno, 2010) kepemimpinan adalah suatu proses kegiatan seseorang untuk menggerakkan orang lain dengan memimpin, membimbing, mempengaruhi orang lain untuk melakukan sesuatu agar dicapai hasil yang diharapkan.

Kepemimpinan adalah setiap tindakan yang dilakukan oleh individu atau kelompok untuk mengkoordinasi dan memberi arahan kepada individu atau kelompok lainnya yang tergabung dalam wadah tertentu untuk mencapai tujuan yang telah diterapkan sebelumnya. Menurut (Handoko, 2013) indikator kepemimpinan adalah sebagai berikut:

1. Kemampuan

Dalam kedudukannya sebagai pegawai mencakup pelaksanaan fungsi-fungsi dasar manajemen, terutama pengarahan dan pengawasan terhadap orang lain.

2. Kebutuhan

Kebutuhan prestasi dalam pekerjaan, mencakup pencarian tanggung jawab dan keinginan sukses.

3. Kecerdasan

Mencakup kebijakan, pemikiran kreatif dan daya fikir.

4. Ketegasan

Kemampuan untuk membuat keputusan-keputusan dan memecahkan masalah masalah dengan cepat, tepat, akurat.

5. Kepercayaan diri

Pandangan terhadap dirinya sebagai kemampuan untuk menghadapi masalah.

6. Kreatif

Kemampuan untuk bertindak tidak bergantung mengembangkan rangkaian kegiatan dan menemukan cara-cara baru, inovasi, pembaharuan, perubahan.

\section{Spiritualitas Di Tempat Kerja}

Spiritualitas di tempat kerja dapat diartikan bahwa tempat kerja sebagai tempat perkumpulan orang yang mempunyai kesatuan pemikiran dan semangat serta percaya bahwa meningkatnya kesemangatan merupakan inti dari meningkatnya suatu pemikiran. Semakin baik karyawan mampu bersemangat di dalam pekerjaannya maka ide atau pemikiran individu akan lebih baik dan dapat mendorong tercapainya tujuan perusahaan. Spiritualitas di tempat kerja didefinisikan sebagai pengakuan bahwa karyawan mempunyai kehidupan batin supaya dapat menjaga dan memelihara pekerjaan yang 
berarti di dalam lingkup organisasi(Ashmos \& Duchon, 2012). Menurut (Pandey et al., 2013) spiritualitas di tempat kerja merupakan sarana bagi individu untuk mengintegrasikan pekerjaan dan spiritualitas mereka, yang akan memberi mereka ketepatan, keterhubungan, dan keutuhan di tempat kerja.

\section{Indikator Spiritualitas di tempat kerja}

Workplace spirituality adalah konsep baru dalam model manajemen dan perilaku organisasi, khususnya budaya organisasi. Konsep ini pun sebenarnya telah digambarkan dalam konsep- konsep perilaku organisasi seperti values, ethics, dan sebagainya.

Spiritualitas di tempat kerja menurut (Milliaman et al., 2013)menyebutkan bahwa spiritualitas di tempat kerja mempunyai 3 dimensi antara lain sebagai berikut:

1. Meaningful work (Pekerjaan yang berarti) Merupakan sebuah aspek fundamental dari spiritualitas di tempat kerja, terdiri dari memiliki kemampuan untuk merasakan makna terdalam dan tujuan dari pekerjaan seseorang. Dimensi spiritualitas di tempat kerja ini merepresentasikan bagaimana pekerja berinteraksi dengan pekerjaan mereka dari hari ke hari di tingkat individu.

2. Alignment with organizational value (Keselarasan dengan nilai organisasi atau keselarasan antar nilai organisasi dan individu). Merupakan aspek fundamental yang ketiga dari spiritualitas di tempat kerja yang mewakili level organisasi. Aspek ketiga ini menunjukan pengalaman individu yang memiliki keberpihakan kuat antara nilainilai pribadi mereka dengan misi dan tujuan organisasi. hal ini berhubungan dengan premis bahwa tujuan organisasi itu lebih besar daripada dirinya sendiri dan seseorang harus memberikan kontribusi kepada komunitas atau pihak lain.

3. Community (Komunitas) Merupakan dimensi spiritualitas di tempat kerja yang merujuk pada tingkat kelompok dari perilaku manusia serta fokus pada interaksi antar pekerja dan rekan kerja mereka.

Indikator-indikator lingkungan kerja menurut (Nitisemito, 2012) terdiri dari:

1. Suasana Kerja

Dalam hal bekerja diperlukan suasana yang nyaman dan sesuai standar dengan

lingkungan kerja pada umumnya. Suasana kerja juga mempengaruhi kesiapan dan semangat karyawan dalam menyelesaikan pekerjaannya, Hal ini tentu juga berpengaruh terhadap kinerja yang dihasilkan karyawan tersebut.

2. Hubungan Karyawan

Dalam sebuah perusahaan tentu dibutuhkan sebuah kerja sama tim baik dalam bagian yang sama maupun antar sesama bagian. Dalam hal ini tentu saja seorang karyawan harus memiliki hubungan yang baik dengan sesama karyawan lainnya karena sebuah pekerjaan biasanya harus diselesaikan oleh seluruh ataupun bebarapa bagian.

3. Tersedianya Fasilitas bagi Karyawan

Dalam hal ini tentu saja hal berperan secara nyata terhadap aktivitas perusahaan. Fasilitas mencakup banyak hal, seperti: gedung, ruangan kerja, pendingin ruangan serta fasilitas penunjang lainnya. Hal ini tentu saja sangat membantu karyawan dalam melakukan pekerjaannya.

\section{Semangat Kerja}

Dalam melakukan suatu pekerjaan perlu adanya semangat kerja. Tanpa adanya semangat kerja, hasil yang didapatkan tidak akan baik dan maksimal. Semangat kerja bisa timbul dari dalam diri sendiri maupun dari lingkungan sekitar yang mendukung adanya semangat. Munurut (Busro, 2018)semangat kerja adalah kondisi rohaniah atau prilaku 
baik individu maupun kelompok yang dapat menimbulkan kesenangan yang mendalam pada diri tenaga kerja untuk bekerja dengan giat dan konsekuen sehingga pekerjaan lebih cepat selesai dan lebih baik serta lebih banyak produk barang dan jasa yang dihasilkan yang semuanya ditujukan dalam rangka mencapai tujuan yang telah ditetapkan perusahaan. Selanjutnya menurut (Malik, 2016)semangat kerja adalah sikap individu atau kelompok untuk bekerja sama melakukan pekerjaan yang lebih giat dan sukarela sehingga pekerjaan dapat diselesaikan dengan lebih cepat dan lebih baik. Selain itu pula setiap anggota kelompok mempunyai kebersamaan tujuan, dengan rasa ikut memiliki setiap aktifitas pekerjaan yang dilakukan, sehingga mempunyai tanggung jawab yang tinggi.

Semangat kerja yang tinggi adalah sebuah suatu kondisi yang sangat diharapkan oleh setiap organisasi. Untuk mengetahui apakah seseorang memiliki semangat kerja yang tinggi atau rendah maka dapat dilihat dari ciri-ciri yang terlibat dalam sikap seharihari. Indikator semangat kerja yang dikemukakan oleh (Nitisemito, 2012)semangat kerja karyawan berkaitan dengan:

1. Produktivitas karyawan

Karyawan yang semangat kerjanya tinggi cenderung melaksanakan tugas-tugas sesuai waktu, tidak menunda pekerjaan dengan sengaja, serta mempercepat pekerjaanya dan sebagainya.

2. Tingkat absensi

Tingkat absensi rendah merupakan salah satu indikasi meningkatnya semangat kerja, karena nampak bahwa presentase absen seluruh karyawan rendah.

3. Tingkat perpindahan karyawan (Labour Turnover)

Keluar masuknya karyawan yang meningkat disebabkan ketidaksenangan mereka dalam bekerja di perusahaan sehingga mereka berusaha mencari pekerjaan yang lain yang di anggap lebih sesuai.

4. Kerusakan

Naiknya kerusakan dapat menunjukan bahwa perhatian dalam bekerja berkurang dan terjadi kecerobohan dalam bekerja.

5. Kegelisahan karyawan

Kegelisahan dapat terwujud dalam bentuk ketidaksenangan dalam bekerja dan keluh kesah yang di ungkapkan di antara sesama karyawan.

6. Tuntutan dari karyawan

Tuntutan merupakan bentuk perwujudan dari ketidakpuasan, dimana pada tahap tertentu akan menimbulkan kebenaran untuk mengajukan tuntutan.

7. Pemogokan kerja oleh karyawan

Pemogokan merupakan bentuk perwujudan dan ketidakpuasan dan kegelisahan, apabila hal ini sudah memuncak dan tidak tertahan lagi maka akan menimbulkan tuntutan, dan jika tidak berhasil pada umumnya berakhir dengan suatu pemogokan.

Sedangkan menurut (As'ad, 2011)juga mengatakan bahwa ada empat indikator yang mempengaruhi semangat kerja yaitu :

1. Kedisiplinan kerja, yaitu usaha untuh mematuhi peraturan yg dikeluarkan organisasi untuk dilaksanakan oleh pegawai.

2. Ketelitian kerja, yaitu sejauh mana pegawai mempunyai rasa kecermatan kerja, sehingga kesalahan dalam berkerja mebjadi sangat rendah.

3. Kegairahan kerja, yaitu adanya keinginan yg tinggi dari pegawai dalam menyelesaikan tugas-tugasnya 
4. Kerajinan kerja, yaitu pegawai dalam mengemban tugas-tugas dan tanggung jawab mempunyai rasa kesungguhan berusaha.

\section{Pengembangan Hipotesis \\ Hubungan Kepemimpinan Terhadap Kinerja}

Hubungan pemimpin dengan anggota berkaitan dengan derajat kualitas emosi dari hubungan tersebut, yang mencakup tingkat keakraban dan penerimaan anggota terhadap pemimpinnya. Semakin yakin dan percaya anggota kepada pemimpinnya, semakin efektif kelompok dalam mencapai tujuannya. Dalam hubungan pemimpin dengan anggotanya perlu diperhatikan antisipasi kepuasan anggota dan harus dipadukan dengan tujuan kelompok, motivasi anggota dipertahankan tinggi, kematangan anggota dalam pengambilan keputusan dan adanya tekat yang kuat dalam mencapai tujuan(Ernaldiwan, 2017). Berdasarkan hasil penelitian terdahulu yang dilakukan oleh (Ernaldiwan, 2017)dan (Tatulus et al., 2015)menyimpulkan bahwa kepemimpinan berpengaruh signifikan terhadap kinerja.

H1 : Kepemimpinan berpengaruh terhadap kinerja pegawai pada kantor Bupati Deli Serdang.

\section{Hubungan Spiritualitas di tempat kerja Terhadap Kinerja}

Spritualitas ditempat kerja adalah kesadaran bahwa orang memiliki kehidupan batin yang tumbuh dan ditumbuhkan oleh pekerjaan yang bermakna yang berlangsung dalam konteks komunitas. Lebih lanjut dijelaskan bahwa, organisasi yang mendukung budaya spritualitas mengakui bahwa manusia memiliki pikiran dan jiwa, berusaha mencari makna dan tujuan dalam pekerjaan mereka, dan hasrat yang berhubungan dengan orang lain, serta menjadi bagian dari sebuah komunitas. Semakin banyak nilai dan aspirasi spiritual kongruen dengan organisasi, maka semakin besar kemungkinan bahwa karyawan akan menemukan makna sebenarnya di tempat kerja sehingga akan meningkatkan kinerja seseorang dalam bekerja (Umam \& Auliya, 2017). Berdasarkan hasil penelitian terdahulu yang dilakukan oleh (Umam \& Auliya, 2017) dan (Marwan et al., 2020) menyimpulkan spiritualitas ditempat bekerja berpengaruh signifikan terhadap kinerja.

H2 : Spiritualitas di tempat kerja berpengaruh terhadap kinerja pegawai pada kantor Bupati Deli Serdang.

\section{Hubungan Semangat Kerja Terhadap Kinerja}

Semangat kerja merupakan suatu gambaran suatu perasaan yang berhubungan dengan tabiat/jiwa semangat kelompok, kegembiraan/ kegiatan, untuk kelompokkelompok pekerja menunjukkan iklim kera dan suasana kerja. Semangat kerja menggambarkan perasaan berhubungan dengan jiwa, semangat kelompok, kegembiraan, dan kegiatan. Apabila pekerja tampak merasa senang, optimis mengenai kegiatan dan tugas, serta ramah satu sama lain, maka pegawai itu dikatakan mempunyai semangat yang tujuan tinggi sehingga pegawai tersebut akan lebih giat untuk melakukan pekerjaan yang pada akhirnya kinerja pegawai tersebut akan semakin meningkat(Kasrini et al., 2016).

Berdasarkan hasil penelitian terdahulu yang dilakukan oleh (Kasrini et al., 2016) dan (Handayani, 2015)menyimpulkan bahwa semangat kerja berpengaruh signifikan terhadap kinerja. Jika semangat kerja sudah dimiliki pada setiap pegawai maka dapat meningkatkan kinerja, dengan cara pegawai memiliki sikap optimis, bertanggung jawab terhadap pekerjaanya serta giat dalam bekerja . 
H3 : Semangat kerja berpengaruh terhadap kinerja pegawai pada kantor Bupati Deli Serdang.

\section{Hubungan Kepemimpinan Terhadap Semangat Kerja}

Keberadaan seorang pemimpin dalam organisasi sangat dibutuhkan untuk membawa organisasi kepada tujuan yang telah ditetapkan. Kepemimpinan merupakan salah satu faktor penting yang dapat mempengaruhi semangat kerja pegawai. Kepemimpinan merupakan inti dari manajemen karena pemimpin adalah motor penggerak bagi seluruh sumber daya suatu organisasi atau perusahaan. Pemimpin sebagai orang pertama dalam sebuah organisasi, hendaknya memiliki kepemimpinan yang baik sehingga dapat diterima oleh pegawai yang menjadi bawahannya.(Siswanto, 2014). Berdasarkan hasil peneltian terdahulu yang dilakukan oleh (Marpaung, 2013)dan (Siswanto, 2014) menyimpulkan bahwa kepemimpinan berpengaruh signidikan terhadap semangat kerja.

H4: Kepemimpinan berpengaruh terhadap semangat kerja pegawai pada kantor Bupati Deli Serdang.

\section{Hubungan Spiritualitas Ditempat Kerja Terhadap Semangat Kerja}

Spiritualitas di tempat kerja dapat diartikan bahwa tempat kerja sebagai tempat perkumpulan orang yang mempunyai kesatuan pemikiran dan semangat serta percaya bahwa meningkatnya kesemangatan merupakan inti dari meningkatnya suatu pemikiran. (Ismail, 2015). Berdasarkan hasil penelitian terdahulu yang dilakukan oleh (Daulay et al., 2017) dan (Ismail, 2015)menyimpulkan bahwa lingkungan kerja berpengaruh signifikan terhadap semangat kerja. Semakin baik karyawan mampu bersemangat di dalam pekerjaannya maka pemikiran individu atau ide ide cemerlang akan terwujud dengan baik dan dapat mendorong tercapainya tujuan perusahaan.

H5 : Spiritualitas di tempat kerja berpengaruh terhadap semangat kerja pegawai pada kantor Bupati Deli Serdang.

\section{METODOLOGI PENELITIAN}

Penelitian dilaksanakan mulai bulan Januari 2021 sampai Juni 2021 dan Penelitian ini dilaksanakan di kantor Bupati Deli Serdang Jl. Negara No.1, Petapahan, Kec. Lubuk Pakam, Kabupaten Deli Serdang, Sumatera Utara 20517. Dan objek yang digunakan seluruh pegawai yang terdapat pada kantor Bupati Deli Serdang berjumlah 122 orang. Variabel dalam penelitian ini terdiri dari Kinerja Pegawai (Y), Kepemimpinan (X1), Spritualitas Di Tempat Kerja (X2), Semangat Kerja (Z). metode yang digunakan dengan pendekatan kuantitatif menggunakan analisis statistik yakni partial least square structural equestion model (PLSSEM) yang bertujuan untuk melakukan analisis jalur (path) dengan variabel laten. Data yang digunakan dalam penelitian ini adalah data primer yaitu data yang diperoleh dan harus diolah kembali, yaitu kuesioner. Dalam melakukan pengumpulan data yang berhubungan dengan yang akan dibahas dilakukan langsung dilakukan dengan dengan cara metode kuesioner. Skala yang dipakai dalam penyusunan adalah skala likert. Skala likert digunakan untuk mengukur sikap, pendapat dan persepsi seseorang atau kelompok orang tentang fenomena sosial. Dalam Pengkurannya, setiap responden diminta pendapatnya mengenai suatu pertanyaan dengan skala penilaian. 


\section{HASIL PENELITIAN DAN PEMBAHASAN}

Tabel 1. Hasil Outer Loading

\begin{tabular}{|l|l|c|c|c|c|l|}
\hline No. & \multicolumn{1}{|c|}{ Butir Pernyataan } & X1 & X2 & Z & Y & Hasil Uji \\
\hline Kepemimpinan(X1) \\
\hline 1. & X1.1 & 0.750 & & & & Valid \\
\hline 2. & X1.2 & 0.703 & & & & Valid \\
\hline 3. & X1.3 & 0.872 & & & & Valid \\
\hline 4. & X1.4 & 0.812 & & & & Valid \\
\hline 5. & X1.5 & 0.820 & & & & Valid \\
\hline 6. & X1.6 & 0.805 & & & & Valid \\
\hline 7 & X1.12 & 0.189 & & & & Valid \\
\hline
\end{tabular}

Spiritualitas ditempat kerja(X2)

\begin{tabular}{|l|l|l|l|l|l|l|}
\hline 1. & X2.1 & & 0.788 & & & Valid \\
\hline 2. & X2.2 & & 0.864 & & & Valid \\
\hline 3. & X2.3 & & 0.787 & & & Valid \\
\hline 4. & X2.4 & & 0.859 & & & Valid \\
\hline 5. & X2.5 & 0.893 & & & Valid \\
\hline 6. & X2.6 & & 0.780 & & & Valid \\
\hline
\end{tabular}

\begin{tabular}{|l|l|l|l|l|l|l|}
\hline Semangat Kerja(Z) & \multicolumn{5}{l|}{} \\
\hline 1. & $\mathrm{Z} 1.1$ & & & 0.762 & & Valid \\
\hline 2. & $\mathrm{Z} 1.2$ & & & 0.742 & & Valid \\
\hline 3. & $\mathrm{Z} 1.3$ & & & 0.731 & & Valid \\
\hline 4. & $\mathrm{Z} 1.4$ & & & 0.742 & & Valid \\
\hline 5. & $\mathrm{Z} 1.5$ & & & 0.928 & & Valid \\
\hline 6. & $\mathrm{Z} 1.6$ & & & 0.889 & & Valid \\
\hline 7. & $\mathrm{Z} 1.7$ & & & 0.171 & \\
\hline
\end{tabular}

\begin{tabular}{|l|l|l|l|l|l|l|}
\hline \multicolumn{2}{|l|}{ Kinerja (Y) } & \multicolumn{3}{l|}{} \\
\hline 1. & Y1.1 & & & & 0.776 & Valid \\
\hline 2. & Y1.2 & & & & 0.645 & Valid \\
\hline 3. & Y1.3 & & & & 0.859 & Valid \\
\hline 4. & Y1.4 & & & & 0.789 & Valid \\
\hline 5. & Y1.5 & & & & 0.801 & Valid \\
\hline 6. & Y1.6 & & & & 0.807 & Valid \\
\hline 7. & Y1.7 & & & & 0.827 & Valid \\
\hline 8 & Y1.8 & & & & \\
\hline
\end{tabular}

(Sumber : Data Diolah, 2021)

Berdasarkan tabel 1 di atas diketahui bahwa nilai outer loading pada setiap indikator adalah lebih dari 0,5. Sehingga dapat disimpulkan bahwa variabel dan indikator yang digunakan dalam penelitian adalah valid. Adapun variabel kepemimpinan yang tidak valid yaitu X7, X8, X9, X10, X11 dan pada variabel Semangat Kerja yaitu Z8. 
Tabel 2 Hasil Cross Loading

\begin{tabular}{|c|c|c|c|c|c|c|}
\hline No. & Butir Pernyataan & $\mathrm{X} 1$ & $\mathrm{X} 2$ & $\mathbf{Z}$ & $\mathbf{Y}$ & Hasil Uji \\
\hline \multicolumn{7}{|c|}{ Kepemimpinan (X1) } \\
\hline 1. & $\mathrm{X} 1.1$ & 0.750 & 0.780 & 0.592 & 0.661 & Valid \\
\hline 2. & $\mathrm{X} 1.2$ & 0.703 & 0.716 & 0.515 & 0.525 & Valid \\
\hline 3. & $\mathrm{X} 1.3$ & 0.872 & 0.742 & 0.695 & 0.859 & Valid \\
\hline 4. & $\mathrm{X} 1.4$ & 0.812 & 0.623 & 0.574 & 0.789 & Valid \\
\hline 5. & $\mathrm{X} 1.5$ & 0.820 & 0.727 & 0.644 & 0.801 & Valid \\
\hline 6. & $\mathrm{X} 1.6$ & 0.805 & 0.643 & 0.660 & 0.776 & Valid \\
\hline 7. & $\mathrm{X} 1.12$ & 0.189 & 0.121 & 0.022 & 0.123 & Valid \\
\hline \multicolumn{7}{|c|}{ Spiritualitas di Tempat Kerja (X2) } \\
\hline 1. & $\mathrm{X} 2.1$ & 0.733 & 0.788 & 0.566 & 0.615 & Valid \\
\hline 2. & $\mathrm{X} 2.2$ & 0.757 & 0.864 & 0.617 & 0.673 & Valid \\
\hline 3. & $\mathrm{X} 2.3$ & 0.585 & 0.787 & 0.637 & 0.594 & Valid \\
\hline 4. & $\mathrm{X} 2.4$ & 0.768 & 0.859 & 0.742 & 0.777 & Valid \\
\hline 5. & $\mathrm{X} 2.5$ & 0.775 & 0.893 & 0.764 & 0.744 & Valid \\
\hline 6. & $\mathrm{X} 2.6$ & 0.750 & 0.780 & 0.592 & 0.661 & Valid \\
\hline \multicolumn{7}{|c|}{ Semangat Kerja $(Z)$} \\
\hline 1. & $\mathrm{Z} 1.1$ & 0.654 & 0.628 & 0.762 & 0.693 & Valid \\
\hline 2. & Z1.2 & 0.472 & 0.513 & 0.742 & 0.573 & Valid \\
\hline 3. & Z1.3 & 0.457 & 0.485 & 0.731 & 0.641 & Valid \\
\hline 4. & $\mathrm{Z} 1.4$ & 0.720 & 0.672 & 0.742 & .0718 & Valid \\
\hline 5. & Z1.5 & 0.767 & 0.808 & 0.928 & 0.802 & Valid \\
\hline 6. & Z1.6 & 0.568 & 0.645 & 0.889 & 0.692 & Valid \\
\hline 7. & Z1.7 & 0.156 & 0.134 & 0.171 & 0.180 & Valid \\
\hline \multicolumn{7}{|c|}{ Kinerja (Y) } \\
\hline 1. & Y1.1 & 0.805 & 0.643 & 0.660 & 0.776 & Valid \\
\hline 2. & Y1.2 & 0.470 & 0.504 & 0.741 & 0.645 & Valid \\
\hline 3. & Y1.3 & 0.872 & 0.742 & 0.695 & 0.859 & Valid \\
\hline 4. & Y1.4 & 0.812 & 0.640 & 0.574 & 0.789 & Valid \\
\hline 5. & Y1.5 & 0.820 & 0.727 & 0.644 & 0.801 & Valid \\
\hline 6. & Y1.6 & 0.760 & 0.758 & 0.643 & 0.807 & Valid \\
\hline 7. & Y1.7 & 0.805 & 0.643 & 0.660 & 0.776 & Valid \\
\hline 8. & Y1.8 & 0.470 & 0.504 & 0.741 & 0.645 & Valid \\
\hline
\end{tabular}

(Sumber : Data Diolah, 2021)

Berdasarkan sajian data pada tabel 2 di atas dapat diketahui bahwa masing-masing indikator pada variabel penelitian memiliki nilai cross loading lebih tinggi pada variabel yang dibentuknya dibandingkan dengan nilai cross loading pada variabel lainnya. Berdasarkan hasil yang diperoleh tersebut, dapat dinyatakan bahwa indikator-indikator yang digunakan dalam penelitian ini telah memiliki discriminant validity yang baik dalam menyusun variabelnya masing-masing.

Tabel 3. Hasil Uji Reliabilitas

\begin{tabular}{|c|c|c|l|}
\hline Variabel / Konstruk & $\begin{array}{c}\text { Cronbach's } \\
\text { Alpha }\end{array}$ & $\begin{array}{c}\text { Composite } \\
\text { Reliability }\end{array}$ & Hasil Uji \\
\hline Kepemimpinan (X1) & $\mathbf{0 . 8 4 5}$ & 0,60 & Reliabel \\
\hline Spiritual di Tempat Kerja (X2) & $\mathbf{0 . 9 0 9}$ & 0,60 & Reliabel \\
\hline Semangat Kerja (Z) & $\mathbf{0 . 8 3 8}$ & 0,60 & Reliabel \\
\hline Kunerja (Y) & $\mathbf{0 . 9 0 7}$ & 0,60 & Reliabel \\
\hline
\end{tabular}

(Sumber : Data Diolah, 2021 
Berdasarkan sajian data pada tabel 3.10 di atas dapat diketahui bahwa masingmasing variabel penelitian memiliki nilai cronbach's alpha dan composite reliability> 0,60 . Berdasarkan hasil yang diperoleh tersebut, dapat dinyatakan bahwa variabel yang digunakan dalam penelitian dinyatakan reliabel.

\section{Analisis Inner Model}

$R$-square adalah ukuran proporsi variasi nilai yang dipengaruhi (endogen) yang dapat dijelaskan oleh variabel yang mempengaruhinya (eksogen) ini berguna untuk memprediksi apakah model adalah baik/buruk. Hasil $r$-square untuk variabel laten endogen sebesar 0,75 mengindikasikan bahwa model tersebut adalah substansial (baik); 0,50 mengindikasikan bahwa model tersebut adalah moderat (sedang) dan 0,25 mengindikasikan bahwa model tersebut adalah lemah (buruk) (Juliandi, 2018). Berdasarkan pengolahan data yang telah dilakukan dengan menggunakan program smartPLS 3.0, diperoleh nilai $R$-Square yang dapat dilihat pada gambar dan tabel berikut:

Tabel 4. Hasil Uji R-Square

\begin{tabular}{|l|ll|ll|}
\hline & R Square & R Square Adjusted & \\
\hline $\mathbf{Y}$ & & 0.931 & & 0.926 \\
\hline
\end{tabular}

\section{Sumber : PLS 3.00}

Dari tabel 4. di atas diketahui bahwa pengaruh X1, X2 dan Z terhadap Y dengan nilai r-square 0,931 mengindikasikan bahwa variasi nilai Y mampu dijelaskan oleh variasi nilai X1, X2 dan Z sebesar 93,1\% atau dengan kata lain bahwa model tersebut adalah substansial (baik), dan 6,9\% dipengaruhi oleh variabel lain.

\section{Pengujian Hipotesis}

Pengujian ini adalah untuk menentukan koefisien jalur dari model struktural. Tujuannya adalah menguji signifikansi semua hubungan atau pengujian hipotesis. Pengujian hipotesis dalam penelitian ini dibagi menjadi pengaruh langsung dan pengaruh tidak langsung. Berdasarkan pengolahan data yang telah dilakukan dengan menggunakan program smartPLS 3.0, gambar hasil uji hipotesis pengaruh langsung dan tidak langsung dapat dilihat pada gambar path coefficient berikut ini :

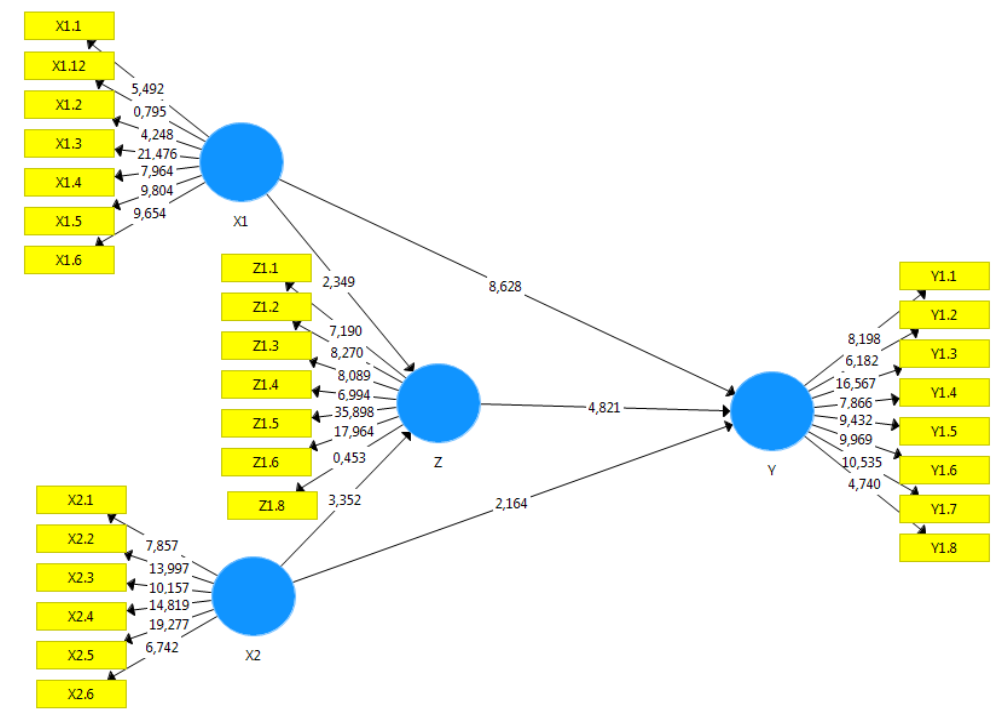

Gambar 1. Path Coefficient 


\section{Pengujian Hipotesis Pengaruh Langsung}

Hasil uji hipotesis pengaruh langsung dapat dilihat pada tabel path coefficient berikut ini:

Tabel 5. Path Coefficient

\begin{tabular}{|c|c|c|c|c|c|}
\hline & $\begin{array}{l}\text { Original } \\
\text { Sample (O) }\end{array}$ & $\begin{array}{l}\text { Sample } \\
\text { Mean (M) }\end{array}$ & $\begin{array}{l}\text { Standard Error } \\
\text { (STERR) }\end{array}$ & $\begin{array}{l}\text { T Statistics } \\
\text { (|O/STERR|) }\end{array}$ & $\begin{array}{l}\mathbf{P} \\
\text { Values }\end{array}$ \\
\hline $\mathbf{X} 1 \rightarrow Y$ & 0,802 & 0,789 & 0,093 & 8,628 & 0.000 \\
\hline $\mathrm{X} 1 \rightarrow \mathrm{Z}$ & 0,329 & 0,344 & 0,140 & 2,349 & 0.019 \\
\hline X2 $>Y$ & $-0,203$ & $-0,180$ & 0,094 & 2,164 & 0.031 \\
\hline $\mathrm{X} 2 \rightarrow \mathrm{Z}$ & 0,503 & 0,494 & 0,150 & 3,352 & 0.001 \\
\hline$Z->Y$ & 0,404 & 0,390 & 0,084 & 4,821 & 0.000 \\
\hline
\end{tabular}

Sumber : PLS 3.00

Berdasarkan Tabel 5 di atas, dapat dinyatakan bahwa pengujian hipotesis adalah sebagai berikut:

1. Pengaruh kepemimpinan terhadap kinerja mempunyai koefisien jalur sebesar 0,802 . Pengaruh tersebut mempunyai nilai probabilitas ( $\mathrm{p}$-values) sebesar 0,000<0,05, berarti kepemimpinan berpengaruh signifikan terhadap kinerja pegawai pada kantor bupati Deli Serdang.

2. Pengaruh kepemimpinan terhadap semangat kerja mempunyai koefisien jalur sebesar 0,329 . Pengaruh tersebut mempunyai nilai probabilitas ( $\mathrm{p}$-values) sebesar $0,019<0,05$, berarti kepemimpinan berpengaruh signifikan terhadap semangat kerja pegawai pada kantor bupati Deli Serdang.

3. Pengaruh spiritual di tempat kerja terhadap kinerja mempunyai koefisien jalur sebesar $-0,203$. Pengaruh tersebut mempunyai nilai probabilitas ( $\mathrm{p}$-values) sebesar $0,031<$ 0,05 , berarti spiritual di tempat kerja berpengaruh negatif dan signifikan terhadap kinerja pegawai pada kantor bupati Deli Serdang.

4. Pengaruh spiritual di tempat kerja terhadap semangat kerja mempunyai koefisien jalur sebesar 0,503. Pengaruh tersebut mempunyai nilai probabilitas ( $\mathrm{p}$-values) sebesar $0,001<0,05$, berarti spiritual di tempat kerja berpengaruh signifikan terhadap semangat kerja pegawai pada kantor bupati Deliserdang.

5. Pengaruh semangat kerja terhadap kinerja mempunyai koefisien jalur sebesar 0,390 . Pengaruh tersebut mempunyai nilai probabilitas (p-values) sebesar $0,000<0,05$, berarti semangat kerja berpengaruh signifikan terhadap kinerja pegawai pada kantor bupati Deli Serdang.

\section{Pengujian Secara Tidak Langsung}

Adapun pengaruh tidak langsung diantara variabel bebas dan variabel terikat pada penelitian ini dapat dikemukakan adalah sebagai berikut :

Tabel 5. Specific Indirect Effects

\begin{tabular}{|l|r|l|l|r|r|}
\hline & $\begin{array}{l}\text { Original } \\
\text { Sample (O) }\end{array}$ & $\begin{array}{l}\text { Sample } \\
\text { Mean } \\
(\mathbf{M})\end{array}$ & $\begin{array}{l}\text { Standard } \\
\text { Deviation } \\
\text { (STDEV) }\end{array}$ & $\begin{array}{l}\text { T Statistics } \\
(\mid \mathbf{O} / \text { STDEV|) }\end{array}$ & P Values \\
\hline $\mathbf{X 1}>\mathbf{Z}>\mathbf{Y}$ & 0.133 & 0.135 & 0.063 & 2,112 & $\mathbf{0 . 0 3 5}$ \\
\hline $\mathbf{X 2}->\mathbf{Z}>\mathbf{Y}$ & 0.203 & 0.193 & 0.075 & 2,709 & $\mathbf{0 . 0 0 7}$ \\
\hline
\end{tabular}

\section{Sumber : PLS 3.00}

Berdasarkan Tabel 5 di atas, dapat dinyatakan bahwa pengujian hipotesis adalah sebagai berikut:

1. Pengaruh kepemimpinan terhadap kinerja melalui semangat kerja mempunyai koefisien jalur sebesar 0,133 . Pengaruh tersebut mempunyai nilai probabilitas ( $p$ values) sebesar $0,035<0,05$, berarti dapat disimpulkan bahwa kepemimpinan 
berpengaruh tidak langsung terhadap kinerja melalui semangat kerja pegawai pada kantor bupati Deli Serdang.

2. Pengaruh spiritual di tempat kerja terhadap kinerja melalui semangat kerja mempunyai koefisien jalur sebesar 0,203 . Pengaruh tersebut mempunyai nilai probabilitas ( $\mathrm{p}$ values) sebesar $0,007<0,05$, berarti dapat disimpulkan bahwa spiritual di tempat kerja berpengaruh tidak langsung terhadap kinerja melalui semangat kerja pegawai pada kantor bupati Deli Serdang.

Tabel 6. Pengaruh Langsung dan Tidak Langsung

\begin{tabular}{|l|c|c|}
\hline \multicolumn{1}{|c|}{ Pengaruh Variabel } & Langsung & Tidak Langsung \\
\cline { 2 - 3 } & & \\
\hline $\mathrm{X} 1 \rightarrow \mathrm{Y}$ & 2,349 & \\
\hline $\mathrm{X} 1 \rightarrow \mathbf{Z} \rightarrow \mathbf{Y}$ & & 2,112 \\
\hline $\mathrm{X} 2 \rightarrow \mathbf{Y} \mathbf{2 , 1 6 4}$ & \\
\hline $\mathrm{X} 2 \rightarrow \mathbf{Z} \rightarrow \mathbf{Y}$ & & 2,709 \\
\hline
\end{tabular}

\section{Sumber : Diolah Peneliti}

Berdasarkan tabel diatas dapat disimpulkan bahwasanya :

4. Semangat kerja tidak dapat memediasi pengaruh kepemimpinan terhadap kinerja dilihat dari hasil $\mathrm{T}$ statistik pengaruh langsung lebih besar dibandingkan dengan $\mathrm{T}$ statistik pengaruh tidak langsung

5. Semangat kerja dapat memediasi pengaruh spiritualitas ditempat kerja terhdap kinerja dilihat dari hasil T statistik pengaruh tidak langsung lebih besar dibandingkan dengan T statistik pengaruh langsung

\section{Pembahasan}

\section{Pengaruh Kepemimpinan Terhadap Kinerja}

Dari hasil analisis pengujian hipotesis diketahui bahwa kepemimpinan berpengaruh signifikan terhadap kinerja yang dinilai dengan koefisien jalur sebesar 0,802 . Nilai probabilitas yang didapatkan adalah sebesar $0,000<0,05$, dengan nilai thitung sebesar 8,628, dan nilai $t_{\text {tabel }} 1.96$, dengan demikian $t_{\text {hitung }}$ lebih besar dari $t_{\text {tabel }}$ (8,628>1.96) sehingga H0 ditolak (Ha diterima). Hal ini berarti kepemimpinanberpengaruh signifikan terhadap kinerja pegawai pada kantor bupati Deli Serdang. Hal ini menunjukkan bahwa kepemimpinan mampu meningkatkan kinerja pegawai pada kantor bupati Deli Serdang, dimana pemimpin memberi semangat kerja, pemberian nasehat, memotivasi pengembangan kemampuan, pendekatan pada aturan dan prosedur kerja serta memberikan teguran dan pujian kepada anggota organisasi sehingga pegawai akan lebih giat dalam melakukan pekerjaanya sehingga kinerja pegawai tersebut akan semakin meningkat. Hubungan pemimpin dengan anggota berkaitan dengan derajat kualitas emosi dari hubungan tersebut, yang mencakup tingkat keakraban dan penerimaan anggota terhadap pemimpinnya. Semakin yakin dan percaya anggota kepada pemimpinnya, semakin efektif kelompok dalam mencapai tujuannya. Dalam hubungan pemimpin dengan anggotanya perlu diperhatikan antisipasi kepuasan anggota dan harus dipadukan dengan tujuan kelompok, motivasi anggota dipertahankan tinggi, kematangan anggota dalam pengambilan keputusan dan adanya tekat yang kuat dalam mencapai tujuan (Ernaldiwan, 2017). Hasil penelitian ini sejalan dengan hasil penelitian terdahulu yang dilakukan oleh (Indajang et al., 2020), (Jufrizen, 2017), dan (Tatulus et al., 2015) menyimpulkan bahwa kepemimpinan berpengaruh signifikan terhadap kinerja. 


\section{Pengaruh Spiritual Di Tempat Kerja Terhadap Kinerja}

Dari hasil analisis pengujian hipotesis diketahui bahwa spiritual di tempat kerja berpengaruh signifikan terhadap kinerja yang dinilai dengan koefisien jalur sebesar 0,302 . Nilai probabilitas yang didapatkan adalah sebesar $0,031<0,05$, dengan nilai thitung sebesar 2,164, dan nilai $t_{\text {tabel }} 1.96$, dengan demikian $t_{\text {hitung }}$ lebih besar dari $t_{\text {tabel }}$ (2,164>1.96) sehingga H0 ditolak (Ha diterima). Hal ini berarti spiritual di tempat kerja berpengaruh signifikan terhadap kinerja pegawai pada kantor bupati Deliserdang. Hal ini menunjukkan bahwa spiritual di tempat kerja mampu meningkatkan kinerja pegawai pada kantor bupati Deliserdang, dimana semakin baikknya spiritual di tempat kerja maka maka semakin besar pegawai akan menemukan makna sebenarnya di tempat kerja sehingga akan meningkatkan kinerja pegawai dalam bekerja. Hasil penelitian ini sejalan dengan hasil penelitian terdahulu yang dilakukan oleh (Umam \& Auliya, 2017) dan (Marwan et al., 2020) menyimpulkan spiritualitas ditempat bekerja berpengaruh signifikan terhadap kinerja.

\section{Pengaruh Semangat Kerja Terhadap Kinerja}

Dari hasil analisis pengujian hipotesis diketahui bahwa semangat kerja berpengaruh signifikan terhadap kinerja yang dinilai dengan koefisien jalur sebesar 0,404 . Nilai probabilitas yang didapatkan adalah sebesar $0,000<0,05$, dengan nilai thitung sebesar 4,821, dan nilai $t_{\text {tabel }} 1.96$, dengan demikian $t_{\text {hitung }}$ lebih besar dari $t_{\text {tabel }}$ (4,821>1.96) sehingga H0 ditolak (Ha diterima). Hal ini berarti semangat kerja berpengaruh signifikan terhadap kinerja pegawai pada kantor bupati Deliserdang. Hal ini menunjukkan bahwa semangat kerja mampu meningkatkan kinerja pegawai kantor bupati Deliserdang, dimana pegawai merasa senang atas apa yang dia terima dan rasakan maka pegawai akan lebih bergairah untuk melakukan pekerjaanya sehingga semangat kerja pegawai akan semakin tinggi. Hasil penelitian ini sejalan dengan hasil penelitian terdahulu yang dilakukan oleh (Kasrini et al., 2016) dan (Handayani, 2015) menyimpulkan bahwa semangat kerja berpengaruh signifikan terhadap kinerja.

\section{Pengaruh Kepemimpinan Terhadap Semangat Kerja}

Dari hasil analisis pengujian hipotesis diketahui bahwa kepemimpinan berpengaruh signifikan terhadap semangat kerja yang dinilai dengan koefisien jalur sebesar 0,329. Nilai probabilitas yang didapatkan adalah sebesar $0,019<0,05$, dengan nilai thitung sebesar 2,349, dan nilai tabel 1.96 , dengan demikian $t_{\text {hitung }}$ lebih besar dari $t_{\text {tabel }}(2,349>1.96)$ sehingga $\mathrm{H} 0$ ditolak (Ha diterima). Hal ini berarti kepemimpuinanberpengaruh signifikan terhadap semangat kerja pegawai pada kantor bupati Deliserdang. Hal ini menunjukkan bahwa kepemimpinan mampu meningkatkan semangat kerja pegawai kantor bupati Deliserdang, dimana sikap pemimpin yang memberikan arahan serta motivasi kepada pegawai dalam melakukan pekerjaan serta pemimpimpin selalu merespon baik atas hasil kerja pegawai sehingga pegawai akan merasa puas atas apa yang diterimanya dengan demikian maka pegawai akan merasa lebih senang dan semangat dalam melakukan pekerjaanya. Hasil penelitian ini sejalan dengan hasil peneltian terdahulu yang dilakukan oleh (Marpaung, 2013) dan (Siswanto, 2014) menyimpulkan bahwa kepemimpinan berpengaruh signifikan terhadap semangat kerja

\section{Pengaruh Spiritualitas Di Tempat Kerja Terhadap Semangat Kerja}

Dari hasil analisis pengujian hipotesis diketahui bahwa spiritual di tempat kerja berpengaruh signifikan terhadap semangat kerja yang dinilai dengan koefisien jalur sebesar 0,503 . Nilai probabilitas yang didapatkan adalah sebesar $0,001<0,05$, dengan nilai thitung sebesar 3,352 , dan nilai $t_{\text {tabel }} 1.96$, dengan demikian $t_{\text {hitung }}$ lebih besar dari 
$t_{\text {tabel }}(3,352>1.96)$ sehingga H0 ditolak (Ha diterima). Hal ini berarti spiritual di tempat kerja berpengaruh signifikan terhadap semangat kerja pegawai pada kantor bupati Deliserdang. Hal ini menunjukkan bahwa spiritual di tempat kerja mampu meningkatkan semangat kerja pegawai kantor bupati Deliserdang, dimana setiap pegawai memiliki pemikiran dan tujuan yang sama untuk mencapai tujuan organisasi maka pegawai akan lebih bergairan untuk menjalankan pekerjaanya serta semangat kerja pegawai akan semakin meingkat. Hasil penelitian ini sejalan dengan hasil penelitian terdahulu yang dilakukan oleh (Daulay et al., 2017) dan (Ismail, 2015) menyimpulkan bahwa spiritual di tempat kerja berpengaruh signifikan terhadap semangat kerja.

\section{Kepemimpinan Terhadap Kinerja Melalui Semangat Kerja}

Dari hasil analisis pengujian hipotesis diketahui bahwa kepemimpinan berpengaruh signifikan terhadap kinerja melalui semangat kerja yang dinilai dengan koefisien jalur sebesar 0,133 . Nilai probabilitas yang didapatkan adalah sebesar $0,035<$ 0,05 , dengan nilai thitung sebesar 2,112, dan nilai $t_{\text {tabel }} 1.96$, dengan demikian $t_{\text {hitung }}$ lebih besar dari $t_{\text {tabel }}(2,112>1.96)$ sehingga H0 ditolak (Ha diterima). Hal ini berarti kepemimpuinan berpengaruh signifikan terhadap kinerja pegawai melalui semangat kerja pegawai pada kantor bupati Deliserdang. Hal ini menunjukkan bahwa kepemimpinan mampu meningkatkan kienrja pegawai melalui semangat kerja pegawai kantor bupati Deliserdang, dimana sikap pemimpin yang memberikan arahan serta motivasi kepada pegawai dalam melakukan pekerjaan serta pemimpimpin selalu merespon baik atas hasil kerja pegawai sehingga pegawai akan merasa puas atas apa yang diterimanya dengan demikian maka pegawai akan merasa lebih senang dan semangat dalam melakukan pekerjaanya dengan semangat kerja pegawai yang tinggi maka kinerja pegawai akan semakin meningkat.

\section{Pengaruh Spiritualitas Di Tempat Kerja Terhadap Kinerja Melalui Semangat Kerja}

Dari hasil analisis pengujian hipotesis diketahui bahwa spiritual di tempat kerja berpengaruh signifikan terhadap kinerja melalui semangat kerja yang dinilai dengan koefisien jalur sebesar 0,203. Nilai probabilitas yang didapatkan adalah sebesar 0,007< 0,05 , dengan nilai thitung sebesar 2,709, dan nilai tabel 1.96, dengan demikian $t_{\text {hitung }}$ lebih besar dari $t_{\text {tabel }}(2,709>1.96)$ sehingga $\mathrm{H} 0$ ditolak (Ha diterima). Hal ini berarti spiritual di tempat kerjaberpengaruh signifikan terhadap kinerja pegawai melalui semangat kerja pegawai pada kantor bupati Deliserdang. Spiritualitas tempat kerja adalah salah satu jenis iklim psikologis di mana orang (pekerja)melihat diri mereka sebagai memiliki kehidupan internal yang dirawat oleh pekerjaan yang bermakna dan ditempatkan dikonteks suatu komunitas. Unit kerja yang memiliki tingkat kerohanian yang tinggi berarti mengalamiiklim, dan dapat diharapkan bahwa unit kerja akan mengalami kinerja yang lebih tinggi (Ashmos \& Duchon, 2012).

\section{KESIMPULAN}

Berdasarkan hasil penelitian dan pembahasan yang telah dikemukakan sebelumnya maka dapat diambil kesimpulan dari penelitian mengenai Pengaruh Kepemimpinan Dan Spiritualitas di tempat kerja Terhadap Kinerja Pegawai Melalui Semangat Kerja Pada Kantor Bupati Deli Serdang adalah sebagai berikut.

1. Secara langsung kepemimpinan berpengaruh signifikan terhadap kinerja pada kantor Bupati Deli Serdang.

2. Secara langsung spiritualitas di tempat kerja berpengaruh signifikan terhadap kinerja pada kantor Bupati Deli Serdang. 
3. Secara langsung semangat kerja berpengaruh signifikan terhadap kinerja pada kantor Bupati Deli Serdang.

4. Secara langsung kepemimpinan berpengaruh signifikan terhadap semangat kerja pada kantor Bupati Deli Serdang.

5. Secara langsung spiritualitas di tempat kerja berpengaruh signifikan terhadap semangat kerja pada kantor Bupati Deli Serdang.

6. Semangat kerja tidak mampu memediasi pengaruh kepemimpinan terhadap kinerja pada kantor Bupati Deli Serdang.

7. Secara tidak langsung semangat kerja mampu memediasi pengaruh spiritual di tempat kerja terhadap kinerja pada kantor Bupati Deli Serdang.

\section{DAFTAR PUSTAKA}

Arianty, N. (2015). Pengaruh Pelimpahan Wewenang dan Koordinasi Kerja Terhadap Pengambilan Keputusan di Perusahaan Asuransi Di Kota Medan. Jurnal Manajemen Tools, 4(2), 80-91.

As'ad. (2011). Seri Ilmu Sumber Daya Manusia: Psikologi Industri. Liberty.

Ashmos, D. P., \& Duchon, D. (2000). Spirituality At Work: A Conceptualization And Measure. Journal of Management Inquiry, 9(2), 134-144.

Busro, M. (2018). Teori Teori Manajemen Sumber Daya Manusia. Kencana.

Daulay, R., Pasaribu, H. K., \& Putri, L. P. (2017). Manajemen. Lembaga Penelitian dan Penulisan Ilmiah AQLI.

Ernaldiwan, F. (2017). Pengaruh Kepemimpinan Terhadap Kinerja Aparatur Sipil Negara di Dinas Sosial Kabupaten Berau. E-Jurnal Ilmu Pemerintahan, 5(1), 255-268.

Handayani, R. D. (2015). Pengaruh Lingkungan dan Semangat Kerja Terhadap Kinerja PNS Balitsa Lembang. Jurnal Pariwisata, 2(1), 1-13.

Handoko, T. H. (2013). Manajemen Personalia dan Sumber Daya Manusia. BPFE Yogyakarta.

Indajang, K., Jufrizen, J., \& Juliandi, A. (2020). Pengaruh Budaya Organisasi Dan Kepemimpinan Kepala Sekolah Terhadap Kompetensi Dan Kinerja Guru Pada Yayasan Perguruan Sultan Agung Pematangsiantar. JUPIIS: Jurnal Pendidikan Ilmu-Ilmu Sosial, 12(2), 393-406. https://doi.org/10.24114/jupiis.v12i2.17881

Ismail. (2015). Pengaruh Lingkungan Kerja Terhadap Semangat Kerja Pegawai Pada Kantor Kecamatan Sesayao Hilir Kabupaten Tana Tidung. Prediksi, 1(1), 1-18.

Jufrizen, J. (2017). Efek Moderasi Etika Kerja Pada Pengaruh Kepemimpinan Transformasional dan Budaya Organisasi Terhadap Kinerja Karyawan. EMabis: Jurnal Ekonomi Manajemen Dan Bisnis, 18(2), 145-158. https://doi.org/10.29103/e-mabis.v18i2.180

Jufrizen, J. (2017). Pengaruh Kepemimpinan dan Budaya Organisasi Terhadap Kinerja dengan Kepuasan Kerja sebagai Variabel Intervening. Jurnal Ilmiah Kohesi, 1(1), 166-177.

Kasrini, K., Paramita, P. D., \& Minarsih, M. M. (2016). Pengaruh Semangat Kerja dan Disiplin Kerja Terhadap Kepuasan Kerja Yang Berdampak Pada Kinerja Pegawai Dinas Pengelolaan Keuangan dan Aset Daerah (DPKAD) Kota Semarang. Journal of Management, 2(2), 1-19.

Malik, N. (2016). Dinamika Pasar Tenaga Kerja Indonesia. Universitas Muhammadiyah Malang.

Mangkunegara, A. A. (2014). Evaluasi Kinerja Sumber Daya Manusia. Refika Aditama. 
Marpaung, R. (2013). Pengaruh Kepemimpinan dan Motivasi Terhadap Semangat Kerja Pegawai Dinas Pertanian, Perternakan dan Perikanan Kabupaten Siak. Jurnal Ekonomi, 21(2), 1-16.

Marwan, M., Rajak, A., \& Abubakar, M. R. (2020). The Effect of Spirituality in the Workplace and Quality of Work Life on Nurses Performance in Regional General Hospital dr. Chasan Boesoerie of North Maluku. Management Insight, 14(1), 1-35.

Milliaman, J., Czaplewski, A. J., \& Fergouson, J. (2003). Workplace spirituality and employee work attitudes an exploratory empirical assessment. Journal of Organizational Chage Management, 16(4), 426-447.

Nitisemito, A. S. (2010). Manajemen Personalia Manajemen Sumber Daya Manusia. Ghalia Indonesia.

Pandey, A., Gupta, R. K., \& Arora, A. P. (2009). Spiritual Climate of Business Organizations and Its Impact on Customers' Experience. Journal of Business Ethics, 88(1), 313-332.

Rahadi, D. R. (2010). Manajemen Kinerja Sumber Daya Manusia. Tunggal Mandiri.

Rivai, V. (2014). Manajemen Sumber Daya Manusia Untuk Perusahaan. PT. Raja Grafindo Persada.

Robbins, S. P. (2012). Perilaku Organisasi. PT. Indeks Kelompok Gramedia.

Silpi, P., Echdar, S., \& Said, M. (2020). Pengaruh Kepemimpinan, Motivasi dan Disiplin Kerja Terhadap Kinerja Aparatur Sipil Negara Badan Kepegawaian dan Pengembangan Sumber Daya Manusia Kabupaten Luwu Timur. JMMNI: Jurnal Magister Manajemen Nobel Indonesia, 1(1), 79-91.

Sutrisno, E. (2010). Manajemen Sumber Daya Manusia. Erlangga.

Tatulus, A., Mandey, J., \& Rares, J. (2015). Pengaruh Kepemimpinan Terhadap Kinerja Pegawau Negeri Sipil Di Kantro Kecamatan Tagulandang Kabupaten Sitaro. Jurnal Administrasi Publik, 2(30), 1-11.

Umam, M. R. K., \& Auliya, Z. F. (2017). Hubungan Kasusalitas Workplace Spirituality dan Kinerja Karyawan: Perspektif Mediasi Etikas Kerja Islam. Bisnis, 5(1), 2350 . 